Miljana Talić ${ }^{1}$

Maja Ivanović Đukić ${ }^{2}$

University of Niš, Faculty of Economics

Tamara Rađenović ${ }^{3}$

University of Niš, Faculty of Occupational Safety
P. $1-13$

ORIGINAL SCIENTIFIC ARTICLE

DOI: $10.5937 / \mathrm{ESD} 2002001 \mathrm{~T}$

Received: May, 01. 2020.

Accepted: Jun, 03. 2020.

\title{
SUSTAINABLE ENTREPRENEURSHIP: CREATING OPPORTUNITIES FOR GREEN PRODUCTS DEVELOPMENT
}

\begin{abstract}
The paper explains the concept of sustainable entrepreneurship, as a sub-concept of social entrepreneurship. The factors influencing the development of sustainable entrepreneurship are examined on the sample of 12,011 entrepreneurs and small and medium-sized enterprises (SMEs) offering a "green product" in 37 countries. The data used in the study are from the Flash Eurobarometer Report 426 (SMEs, Resource Efficiency and Green Markets). The results revealed that, according to the perception of sustainable entrepreneurs, the biggest impact on starting and developing a business in the environmental sphere can have: financial incentives, measures related to easier market access, technical assistance in the development of "green product", and advisory assistance in marketing and distribution of "green product".
\end{abstract}

Key words: sustainable entrepreneurship, green product, financial incentives.

JEL classification: L31, O35, Q52

\section{ОДРЖИВО ПРЕДУЗЕТНИШТВО: СТВАРАҢЕ МОГУЋНОСТИ ЗА РАЗВОЈ ЗЕЛЕНИХ ПРОИЗВОДА}

\section{Апстракт}

У раду је објашњен концепт одрживог предузетништва, као подконцепт који се развио из социјалног предузетништва. Анализирани су фактори који утичу на развој одрживог предузетништва, на узорку од 12.011 предузетника и малих и средюих предузећа (МСП) који нуде ,зелени производ “у 37 земаља. Подации коришћени у студији су из извештаја "Flash Eurobarometer 426”. Резултати су показали да, према периепцији одрживих предузетника, највећи утииај на покретање и развој посла у еколошкој сфери могу имати: финансијски подстииаји, мере везане за лакши приступ тржишту, техничка

\footnotetext{
${ }^{1}$ tmiljana@hotmail.com, ORCID ID 0000-0003-1017-8788

${ }^{2}$ maja.djukic@eknfak.ni.ac.rs, ORCID ID 0000-0002-0547-7209

${ }^{3}$ tamara.radjenovic@znrfak.ni.ac.rs, ORCID ID 0000-0003-1632-7772
} 
помоћ у развоју „зеленог производа“ и саветодавна помоћ у области маркетинга и дистрибуиије ,зеленог производа“.

Кључне речи: одрживо предузетништво, зелени производ, финансијски подстииаји

\section{Introduction}

The massive use of fossil fuels during the $20^{\text {th }}$ century caused the "greenhouse effect", worrying about climate change, and many other environmental problems. This has led to the actualization of the issue of sustainable development (Krstić \& IvanovićĐukić, 2011). To address this issue, several declarations have been adopted (UN Convention on Climate Change in Rio de Janeiro, Kyoto Protocol) committing states to use natural resources more efficiently and encourage activities that lead to the preservation of the environment. In most countries, environmental legislation is in force, which obliges economic entities to respect environmental principles, i.e. to reduce the emission of harmful gases, increase energy efficiency, and increase the efficient use of natural resources. At the same time, a large number of incentives are provided for companies that contribute to the protection of the environment, apply cleaner technologies, and consume natural resources rationally. Also, incentives are provided for individuals who introduce environmental innovations and start new businesses in which these innovations are implemented, i.e. "sustainable entrepreneurs" (Hoogendoorn et al., 2019).

Sustainable entrepreneurs are individuals who start a business to solve some environmental problems (they offer so-called "green products") in an economically sustainable way (Hockerts \& Wustenhagen, 2010; York et al., 2016). These socially and environmentally conscious individuals fulfill a vital role in society because they offer solutions to complex environmental problems which are neglected or ignored by government, existing companies, or society (Shepherd \& Patzelt, 2011). More broadly, they are motivated to contribute to sustainable development, i.e. "meeting the needs of present generations without compromising the ability of future generations to meet their own needs" (WCED, 1987, p. 43).

Sustainable entrepreneurship is of great importance for society and the environment. However, establishment and development of a business in the field of ecology are influenced by a much larger number of factors compared to the development of a classic commercial company. In order to stimulate the establishment of companies that offer "green products" and encourage their development, it is necessary to identify the factors that have the greatest impact (both positive and negative) on their business. The subject of this paper is the identification of key success factors of companies in the environmental sphere.

The paper is structured as follows. After the brief explanation of the concept of sustainable entrepreneurship, the analysis of the factors that have a stimulating and limiting effect on the development of sustainable entrepreneurship will be presented. Finally, based on Flash Eurobarometer data, the success factors of companies offering "green products" in 37 countries will be analyzed and discussed. 


\section{Literature review}

\subsection{The roots of sustainable entrepreneurship}

Many countries in Europe in the 1980s had a problem with unemployment, which they could not solve with the existing mechanisms of social policy. New solutions had to be found that would enable certain social groups (such as: long-term unemployed people, low-skilled workers, people with disabilities, people older than 50, members of ethnic communities, single parents, spouses from families in which both spouses are unemployed, people who have been serving a prison sentence, people who face existential difficulties due to addiction to alcohol, drugs or other intoxicants, after completing rehab programs, etc.) to participate in the labor market (Certo \& Miller, 2008). As a possible solution to this problem, it has begun the establishment of social enterprises.

Social enterprises appeared as innovations in the public sector, whose primary goal was to care for socially vulnerable groups and to train people who were disadvantaged in society and could not be self-employed. The first social enterprise was founded in 1991 in Italy in the form of a cooperative (cooperative sociale) and was called a social cooperative. Very soon, the establishment of social enterprises has begun in other European countries (Raičević \& Glomazić, 2012, p. 7).

Initially, social enterprises were founded and financed by the state, but very quickly members of civil society (citizens, informal groups, associations, etc.) organized themselves. They independently established social enterprises in various legal forms in order to enable employment of people who were long-term unemployed and facilitate their inclusion in social flows (Hjorth, 2013; Monzón \& Chaves, 2017), or offered goods/ services to the most vulnerable social groups (children without parental care, people older than 70, homeless people, people with special needs, etc.), at relatively low prices or completely free of charge, and facilitated overcoming the institutional vacuum (Kolin \& Petrušić, 2008).

These individual initiatives included finding new and original ideas for solving social problems, starting a business while providing all the necessary resources and bearing the risk of failure of such business. In other words, they had all the elements of entrepreneurial activity, so they began to be considered as a form of entrepreneurship (Austin et al., 2006). Unlike traditional entrepreneurial ventures who were aimed at making a profit, these initiatives were aimed at solving social problems (Certo \& Miller, 2008). Also, unlike traditional entrepreneurs who employed the most productive workforce, these entrepreneurial initiatives gave preference to members of hard-toemploy social groups (Mair \& Marti, 2006; Austin et al., 2006). Since, the elements of traditional entrepreneurship were applied in the social sphere, the term social entrepreneurship appeared (Zahra et al., 2009; Elkington \& Hartigan, 2008).

The benefits of implementing an individual entrepreneurial initiative in the social sphere, to solve social problems, were noticed by many international institutions, and hence they have started working on its promotion and development by implementing incentive measures (Hjorth, 2013). These measures have resulted in the emergence of a large number of social enterprises and entrepreneurs who are focused on solving social problems (EC, 2013). The diversity of social problems resulted in establishment of social enterprises with very different social missions. Among them, social enterprises in the 
field of ecology stand out. The increase in the number of social enterprises in the field of ecology has led to the emergence of a new concept called sustainable entrepreneurship.

\subsection{The development of sustainable entrepreneurship}

Sustainable entrepreneurship implies "discovering, creating and using entrepreneurial opportunities that contribute to the sustainability of the environment" (Groot \& Pinkse, 2015, p. 634). Sustainable entrepreneurs are motivated to have a positive impact on complex and often interrelated social and environmental issues, such as climate change, nuclear radiation, unequal access to health care and education, poverty and long-term unemployment (York et al., 2016).

According to Hockerts and Wustenhagen (2010), sustainable entrepreneurship originated in the field of social entrepreneurship as a concept that solves a group of social problems related to the environment by offering environmentally sustainable "green products" (such as waste recycled products, electricity from renewable sources, etc.). Social and sustainable entrepreneurship share focus on solving social problems and strive to increase the quality of life for the benefit of others, unlike commercial entrepreneurs whose goal is to make a profit (Groot \& Pinkse, 2015; Santos, 2012; Schaltegger \& Wagner, 2011). Also, the common goal of social and sustainable entrepreneurs is to employ members of marginalized social groups, as opposed to commercial entrepreneurs who employ the most productive workforce (Dacin et al., 2010).

Despite many common features, social and sustainable entrepreneurship differ in many aspects, including the domain of social goals. Social entrepreneurs have primarily the goal of increasing social and economic equality in society, by creating various forms of social benefits through solving social problems, such as increasing access to health care or providing sanitation and water in areas where it is needed (Thompson et al., 2011). Whereas, environmental entrepreneurs want to protect the natural environment or recover natural ecosystems (York \& Venkataraman, 2010). They do so in a for-profit context that combines the creation of environmental and economic value (York et al., 2016).

Sustainable entrepreneurs explicitly focus on a combination of social, environmental, and economic goals (Shepherd \& Patzelt, 2011) and formulate this as "preserving nature and communities in search of opportunities to create future products and services, with profits largely reduced to economic and non-economic the gains of individuals, the economy and society". As such, sustainable entrepreneurs are of great importance to the community (they help solve the chosen environmental problem, often employ members of hard-to-employ groups and organize business in an economically sustainable way).

Schaltegger and Wagner (2011) indicate that the survival of a company in the environmental sphere depends on the success of balancing the rational use of resources (to gain a competitive advantage) and the success in solving the chosen environmental problem/characteristics of a green product (to gain the trust of local stakeholders and built legitimacy in society). In other words, the survival and success of sustainable entrepreneurs are conditioned by the action of a large number of economic and social factors. 


\section{Methodology}

\subsection{The development of hypotheses related to the success factors of sustainable entrepreneurship}

Sustainable entrepreneurs introduce eco-innovation to make it easier to solve environmental problems, often employ hard-to-employ people, and at the same time strive to make a profit to make their business economically viable (Groot \& Pinkse, 2015; Dean \& McMullen, 2007). The presence of dual goals (economic and environmental (social)) also creates additional challenges compared to commercial entrepreneurs. Also, a larger number of support forms can be an incentive for the development of sustainable entrepreneurship.

Previous research shows that financial incentives have a great influence on starting new businesses (Stefanović et al., 2013). Lack of capital to start a business is one of the most serious barriers for entrepreneurs. Barriers of a financial nature are even more pronounced in social entrepreneurship (Dorado, 2006; Zahra et al., 2009) and sustainable entrepreneurship (Groot \& Pinkse, 2015; Dean \& McMullen, 2007).

With regard to social entrepreneurship, several studies have shown that social entrepreneurs face a much greater number of difficulties in obtaining financial resources compared to commercial entrepreneurs (Dorado, 2006; Purdue, 2001; Sharir \& Lerner, 2006). First of all, the return on investment in social enterprises is difficult to estimate (because profit is not primary, as in commercial enterprises), which makes it difficult or impossible for social entrepreneurs to access the capital market (Zahra et al., 2009). When it comes to sustainable entrepreneurs, the situation is very similar. For example, a survey in the UK led by Social Enterprise shows that funding is perceived as a strong barrier to the growth of sustainable entrepreneurship (Leahy \& Villeneuve-Smith, 2009).

In addition to difficulties with the lack of standardized measures for evaluating results, similar to social entrepreneurs (Zahra et al., 2009), sustainable entrepreneurs are hindered in attracting capital due to significant spillovers of values resulting from the existence of positive externalities (Dean \& McMullen, 2007). Positive externalities create significant and desirable social gains. This problem, called the double external problem (Rennings, 2000), is particularly relevant when considering natural resource and environmental issues (Jaffe et al., 2005). As a result, favorable sources of funding and grants can be extremely important for the development and creation of "green products". In this sense, our hypothesis is:

\section{H1: Financial incentives have the greatest impact on starting and developing a business in the environmental sphere.}

In addition to financial barriers, entrepreneurs face a large number of non-financial ones, such as: prevailing industrial norms, that make it difficult to access the market; administrative procedures, that slow down and increase the cost of starting a business; legal regulations and their compliance, that affect unfair competition; and the like (Groot \& Pinkse, 2015; Hockerts \& Wustenhagen, 2010).

Market access has a great impact on business development in the environmental sphere (Hoogendoorn et al., 2019). If a company is established in social protection or service industries, barriers to market entry are generally low, as capital investment 
is usually modest and often does not require a highly skilled workforce, competition generally does not benefit from economies of scale, nor does it have well-known brands and loyal consumers. Thanks to that, sustainable entrepreneurs can relatively easily attract consumers and access the market.

However, starting a business in other industries (manufacturing, energy, construction) can encounter numerous barriers related to: the use of public goods (nature parks, protected ecological habitats, etc.), externalities effects, the monopoly power of public enterprises (Dean \& McMullen, 2007; Groot \& Pinkse, 2015; Pacheco et al., 2010). Also, certain barriers can be created by the lack of information important for the economic viability of future business (for example, the cost of using certain natural resources, their exhaustion, unclear property rights over certain resources and conditions of their use, etc.), which discourages their decision to start a sustainable business (Cohen \& Winn, 2007). Adequate support related to market access, attracting consumers and retaining them can have a huge impact on business development. In this sense, our next hypothesis is:

\section{H2: Assistance in identifying potential markets or customers has a significant impact on the sales (placement) of "green products" and the development of sustainable entrepreneurship.}

The next factor that has a great impact on the development of companies in the field of ecology is the knowledge and experience related to the development of the "green product" (Edelman \& Yli-Renko, 2010; De Marchi, 2012). Also, in this area there may be very complex administrative procedures when starting a business. Starting a business in some environmental areas, such as the use of natural resources and renewable energy sources, requires a huge number of permits and approvals (Marin et al., 2015). In countries where the number of administrative procedures is large, this can be an extremely big barrier, as it increases the time and cost of starting a business (Rizos et al., 2015). Therefore, technical support for the development of products, services and production processes and assistance in resolving administrative procedures can be of great importance for the development of business in the field of ecology. Accordingly, our next hypothesis is:

\section{H3: Technical support for the development of products, services and production processes and assistance in resolving administrative procedures can be of great importance for the development of business in the field of ecology.}

Sustainable entrepreneurs help solve the problems of their social community, give a certain contribution to society, and hence, they expect some support from the same social community in promoting their products (Pacheco et al., 2010). Promoting "green products" raises the awareness of the population (potential consumers) about the role and importance of sustainable entrepreneurship and encourages the purchase of "green products", whose prices are usually not low (due to the large share of labor costs, because many jobs are done manually) (Hansen \& Schaltegger, 2013). Also, promotion organized by local authorities can influence the trust of the population, potential consumers, towards the products and services of sustainable entrepreneurs, which can be of great importance in the initial period (Dean \& McMullen, 2007; Groot and Pinkse, 2015; Pacheco et al., 2010). Our last hypothesis is: 
H4: Consultancy services for marketing or distribution have a significant impact on the development of sustainable entrepreneurship.

\subsection{Model and variables}

The Flash Eurobarometer data from 2015 are used for the analysis. The sample includes 37 countries: The United States, 28 EU member states and eight non-EU European countries (EC, 2015). The list of countries is presented in Table 1.

Table 1: List of countries included in the survey

\begin{tabular}{|l|l|l|l|l|l|}
\hline No. & Country & No. & Country & No. & Country \\
\hline 1 & Belgium & 15 & Luxemburg & 29 & Turkey \\
\hline 2 & Bulgaria & 16 & Hungary & 30 & Croatia \\
\hline 3 & Czech Rep. & 17 & Moldavia & 31 & Macedonia \\
\hline 4 & Denmark & 18 & Netherlands & 32 & Montenegro \\
\hline 5 & Germany & 19 & Austria & 33 & Serbia \\
\hline 6 & Estonia & 20 & Poland & 34 & Albania \\
\hline 7 & Ireland & 21 & Portugal & 35 & Island \\
\hline 8 & Greece & 22 & Romania & 36 & Norway \\
\hline 9 & Spain & 23 & Slovenia & 37 & USA \\
\hline 10 & France & 24 & Slovakia & & \\
\hline 11 & Italy & 25 & Finland & & \\
\hline 12 & Cyprus & 26 & Sweden & & \\
\hline 13 & Lithuania & 27 & Ukraine & & \\
\hline 14 & Latvia & 28 & Great Britain & & \\
\hline
\end{tabular}

Source: Flash Eurobarometer 426: SMEs, Resource Efficiency and Green Markets. Report https://ec.europa.eu/commfrontoffice/publicopinion/index.cfm/Survey/ getSurveyDetail/instruments/FLASH/surveyKy/2088/p/2

There were 13,114 companies in the sample, of which $201(1.5 \%)$ were large companies, medium-sized companies participated with $3.5 \%$, small companies with $16 \%$, while entrepreneurs accounted for $79 \%$ (of which as many as $83 \%$ were one-person companies).

The number of entrepreneurs and SMEs offering a "green product" is taken as a measure of sustainable entrepreneurship. These companies accounted for $28.24 \%$. Companies that plan to introduce a "green product" accounted for $7.7 \%(3,453)$ while the remaining $64 \%$ were commercial companies that do not plan to introduce "green products". The analysis was done only on a sample of sustainable companies and entrepreneurs. The structure of sustainable enterprises and entrepreneurs is presented in Table 2. 
Table 2: Sample structure of sustainable enterprises and entrepreneurs by size

\begin{tabular}{|l|c|c|}
\hline Category & Participation in \% & Number \\
\hline Entrepreneurs & 79 & 2,728 \\
\hline Small-sized enterprises & 16 & 552 \\
\hline Medium-sized enterprises & 3.5 & 121 \\
\hline Large companies & 1.5 & 52 \\
\hline Total & $\mathbf{1 0 0}$ & $\mathbf{3 , 4 5 3}$ \\
\hline
\end{tabular}

Source: Flash Eurobarometer 426: SMEs, Resource Efficiency and Green Markets.

Report https:/lec.europa.eu/commfrontoffice/publicopinion/index.cfm/Survey/ getSurveyDetail/instruments/FLASH/surveyKy/2088/p/2

Entrepreneurs' perception about the support measures, which can contribute to the development of their business, is analyzed. First, entrepreneurs were interviewed about the way in which they provided resources and competencies for the development of "green products" in the previous period. Only 23\% (767) of entrepreneurs and SMEs stated that they used external support, while the remaining $77 \%$ used their own resources and competencies to develop "green products". The forms of external support used by sustainable entrepreneurs and SMEs are shown in Table 3.

Table 3: Forms of external support used by sustainable entrepreneurs and SMEs

\begin{tabular}{|l|c|c|}
\hline Forms of external support & Number & Structure \\
\hline Public funding such as grants, guarantees or loans & 92 & $12 \%$ \\
\hline $\begin{array}{l}\text { Private funding from a bank, investment company } \\
\text { or venture capital fund }\end{array}$ & 115 & $15 \%$ \\
\hline Private funding from friends or relatives & 23 & $3 \%$ \\
\hline $\begin{array}{l}\text { Advice or other non-financial assistance from } \\
\text { public administration }\end{array}$ & 100 & $13 \%$ \\
\hline $\begin{array}{l}\text { Advice or other non-financial assistance from } \\
\text { private consulting and audit companies }\end{array}$ & 176 & $23 \%$ \\
\hline $\begin{array}{l}\text { Advice or other non-financial assistance from } \\
\text { business associations }\end{array}$ & 207 & $27 \%$ \\
\hline Other & 54 & $7 \%$ \\
\hline Total & $\mathbf{7 6 7}$ & $\mathbf{1 0 0 \%}$ \\
\hline
\end{tabular}

Source: Flash Eurobarometer 426: SMEs, Resource Efficiency and Green Markets. Report https://ec.europa.eu/commfrontoffice/publicopinion/index.cfm/Survey/ getSurveyDetail/instruments/FLASH/surveyKy/2088/p/2

\subsection{Results and discussion}

Measures of descriptive statistics for perceived barriers and sustainability are presented in Table 4. 
Table 4: Descriptive statistics

\begin{tabular}{|c|c|c|c|c|}
\hline & Total & Mean & Min & Max \\
\hline 1. Number of entrepreneurs and SME & 12,011 & & & \\
\hline 1. Offer green product & 3,392 & 107 & 16 & 208 \\
\hline 2. Don't offer green product, but plan to introduce it & 927 & 34 & 4 & 61 \\
\hline 3. Don't plan to introduce green product & 7,742 & 223 & 49 & 397 \\
\hline 2. Forms of support & 3,392 & & & \\
\hline $\begin{array}{l}\text { a) Financial incentives for developing products, services } \\
\text { or new production processes }\end{array}$ & 1,183 & 52 & 4 & 97 \\
\hline b) $\begin{array}{l}\text { Assistance in identifying potential markets or } \\
\text { customers }\end{array}$ & 1,069 & 38 & 3 & 69 \\
\hline $\begin{array}{l}\text { c) Technical support for the development of products, } \\
\text { services and production processes }\end{array}$ & 939 & 42 & 0 & 84 \\
\hline d) Consultancy services for marketing or distribution & 764 & 32 & 1 & 64 \\
\hline
\end{tabular}

Source: Flash Eurobarometer 426: SMEs, Resource Efficiency and Green Markets. Report https://ec.europa.eu/commfrontoffice/publicopinion/index.cfm/Survey/ getSurveyDetail/instruments/FLASH/surveyKy/2088/p/2

Out of a total of 12,011 surveyed entrepreneurs and SMEs, 3,392 (26\%) currently offer "green products", 927 SMEs (7\%) plan to introduce "green products" in the next 2 years, while 7,742 do not plan to introduce "green products" in the near future. The highest number of SMEs and entrepreneurs (SMEEs) offering "green products" was 208, in Austria and the lowest in Montenegro, only 16. The largest number of SMEEs not planning to introduce "green products" was in Hungary 377.

Major problems for SMEs are limited financial resources and difficulties in securing resources for funding eco-innovation. As financial and other resources have to be provided and invested well before generating revenue, SMEs are forced to provide capital to finance environmental innovations from external sources. Another problem that builds on the previous one is the difficulty for SMEs to access the capital market, and hence, innovations are most often financed through bank loans or risk capital funds. Additionally, innovation financing through bank loans is generally unsatisfactory due to the high risk and unfavorable conditions for borrowing funds (Krstić \& Ivanović-Đukić, 2011). For these reasons, SMEEs rarely decide to implement environmental innovations.

However, financial incentives would significantly affect the greater implementation of environmental innovations. The largest number of sustainable entrepreneurs 1,183 (35\%) believe that financial incentives can have a significant impact on the development of the "green product", which is in line with our first hypothesis. Among them the largest number of sustainable entrepreneurs is from Ireland (97), and the smallest from Albania.

Also, a large number of sustainable entrepreneurs $(1,069)$ believe that assistance in identifying potential markets or customers can have a significant impact on the development and marketing of the "green product", which is in line with our second assumption. The greatest importance is given to this factor in Ireland (69), and the least (3) in Albania, Macedonia and Montenegro.

The situation is similar in the area of technical support for the development of products, services and production, where 939 sustainable entrepreneurs believe that this 
measure can be important for the development of their business. The highest number of SMEs is in France (84), and the lowest in Albania (0). Although, some SMEs are willing and able to adopt sustainable practices, they generally face a lack of certain resources, i.e. skills shortages and limited knowledge. Lack of appropriate skills and expertise usually prevents entrepreneurs from acting in the field of eco-innovation, even when they are aware that better environmental performance can lead to improved competitiveness. Free technical assistance can help SMEs ensure their initial engagement in green practices (OECD, 2015).

Finally, the smallest number of sustainable entrepreneurs gives importance to advisory support in the field of marketing and distribution (764, i.e. 23\%). The highest number is in Austria and Finland (64), and the lowest in Serbia (1). Several studies conducted in the UK have shown that SMEs mainly use the advice of their accountants in most areas of their business (Spence et al., 2012). Accountants are the ones who routinely give advice to SMEEs not only on taxation and financial management, but also on a number of organizational issues, marketing, and strategic planning (OECD, 2015).

\section{Conclusion}

The concept of sustainable entrepreneurship, which refers to starting new businesses in the environmental sphere to solve a certain environmental problem in an economically sustainable way, is explained (Cohen \& Winn, 2007). Sustainable entrepreneurs have double goals - economic and environmental. For that reason, establishment and development of their business are influenced by a much larger number of factors compared to commercial entrepreneurs.

Based on Flash Eurobarometer (2015) data for 12,011 entrepreneurs and SMEs in 37 countries offering a "green product", the impact of various factors that may influence the establishment and development of business in the environmental sphere was examined. According to the perception of sustainable entrepreneurs, the biggest impact on starting and developing a business can have: financial incentives, measures related to market access, technical assistance in the development of "green product", and advisory assistance in the field of marketing and distribution of "green product".

In order to encourage the development of sustainable entrepreneurship and increase the number of SMEEs introducing "green product", it is necessary to implement various measures. The establishment of sustainable incubators is a measure that can stimulate the establishment of new companies in the environmental sphere. The incubator can offer various consulting services related to the development of "green product", its distribution, and sale. According to the opinion of entrepreneurs who currently offer "green product" these support forms would be the most useful. Also, it is desirable to offer a large number of financial incentives (in the form of subsidies, grants, favorable sources of funding, guarantees, etc.), for the development and commercialization of "green products". 


\section{References}

Austin, J., Stevenson, H., \& Wei-Skillern, J. (2006). Social and commercial entrepreneurship: Same, different, or both? Entrepreneurship Theory \& Practice, $30(1), 1-22$.

Certo, S., \& Miller, T. (2008). Social entrepreneurship: Key issues and concepts. Business Horizons, 51(4), 267-271.

Cohen, B., \& Winn, M. I. (2007). Market imperfections, opportunity and sustainable entrepreneurship. Journal of Business Venturing, 22(1), 29-49.

Dacin, P. A., Dacin, M. T., \& Matear, M. (2010). Social entrepreneurship: Why we don't need a new theory and how we move forward from here. Academy of Management Perspectives, 24(2), 36-56.

De Marchi, V. (2012). Environmental innovation and R\&D cooperation: Empirical evidence from Spanish manufacturing firms. Research Policy, 41(3), 614-623.

Dean, T. J., \& McMullen, J. S. (2007). Toward a theory of sustainable entrepreneurship: Reducing environmental degradation through entrepreneurial action. Journal of Business Venturing, 22(1), 50-76.

Dorado, S. (2006). Social entrepreneurial ventures: Different values so different process of creation, no? Journal of Developmental Entrepreneurship, 11(4), 319-343.

EC (2013). Social Economy and social entrepreneurship, Social Europe Guide, European Commission.

EC (2015). Flash Eurobarometer 426. SMEs, Resource Efficiency and Green Markets. European commission Report (Accessed July 20, 2020). https://ec.europa.eu/ commfrontoffice/publicopinion/index.cfm/Survey/getSurveyDetail/instruments/ FLASH/surveyKy/2088/p/2

Edelman, L., \& Yli-Renko, H. (2010). The impact of environment and entrepreneurial perceptions on venture-creation efforts: bridging the discovery and creation views of entrepreneurship. Entrepreneurship Theory and Practice, 34(5), 833-856.

Elkington, J., \& Hartigan, P. (2008). The power of unreasonable people: How social entrepreneurs create markets that change the world. Boston: Harvard Business Press.

Groot, K., \& Pinkse, J. (2015). Sustainable entrepreneurship and corporate political activity: Overcoming market barriers in the clean energy sector. Entrepreneurship Theory and Practice, 39(3), 633-654.

Hansen, E. G., \& Schaltegger, S. (2013). 100 per cent organic? A sustainable entrepreneurship perspective on the diffusion of organic clothing. Corporate Governance, 13(5), 583-598.

Hjorth, D. (2013). Public Entrepreneurship: Desiring Social Change, Creating Sociality. Entrepreneurship and Regional Development, 25(1-2), 34-51.

Hockerts, K., \& Wustenhagen, R. (2010). Greening Goliaths versus emerging Davids - Theorizing about the role of incumbents and new entrants in sustainable entrepreneurship. Journal of Business Venturing, 25(5), 481-492. 
Hoogendoorn, B., Zwan, P., \& Thurik, R. (2019). Sustainable Entrepreneurship: The Role of Perceived Barriers and Risk, Journal of Business Ethics, 157 (3), 1133 1154.

Jaffe, A. B., Newell, R. G., \& Stavins, R. N. (2005). A tale of two market failures: Technology and environmental policy. Ecological Economics, 54(2), 164-174.

Jovanović, O., \& Zubović, J. [2019]. The importance of subsidies for SME development in the agricultural sector of Serbia. Western Balkan Journal of Agricultural Economics and Rural Development, 1(1), 51-61.

Kolin, M., \& Petrušić, N. (2008). Socijalna preduzeća i uloga alternativne ekonomije u procesima Evropskih integracija. Beograd: Evropski pokret u Srbiji.

Krstić, B., \& Ivanović-Đukić, M. (2011) Ostvarivanje energetske efikasnosti kao ekološke dimenzije održivog razvoja u funkciji unapređenja konkurentnosti MSP u Srbiji, Regionalni razvoj i demografski tokovi zemalja Jugoistočne Evrope, Ekonomski fakultet Niš, jun 2011, str. 619-634.

Leahy, G., \& Villeneuve-Smith, F. (2009). State of social enterprise survey. London: Social Enterprise Coalition.

Mair, J., \& Marti, I. (2006). Social entrepreneurship research: A source of explanation, prediction, and delight. Journal of World Business, 41(1), 36-44.

Marin, G., Marzucchi, A., \& Zoboli, R. (2015). SMEs and barriers to Eco-innovation in the EU: exploring different firm profiles. Journal of Evolutionary Economics, 25(3), 671-705.

Monzón, J. L., \& Chaves, R. (2017). Recent evolutions of the Social Economy in the European Union. Bruxelles: European Economic and Social Committee.

OECD (2015). Environmental Policy Toolkit for SME Greening in EU Eastern partnership countries. Organisation for Economic Co-operation and Development, Paris.

Pacheco, D. F., Dean, T. J., \& Payne, D. S. (2010). Escaping the green prison: Entrepreneurship and the creation of opportunities for sustainable development. Journal of Business Venturing, 25(5), 464-480.

Petrović, M., \& Leković, B. [2019]. Karakteristike ambicioznih preduzetnika u Jugoistočnoj Evropi - koncept očekivanja visokog rasta poduhvata. Anali Ekonomskog fakulteta u Subotici, (41), 55-66.

Purdue, D. (2001). Neighborhood governance: Leadership, trust and social capital. Urban Studies, 38(12), 2211-2224.

Raičević, V., \& Glomazić, R. (2012). Značenje i oblici socijalnog preduzetništva, Beograd: Friedrich Ebert Stiftung.

Rizos, V., Behrens, A., Kafyeke, T., Hirschnitz-Garbers, M., \& Ioannou, A., (2015). The circular economy: Barriers and opportunities for SMEs. Brussels: CEPS.

Rennings, K. (2000). Redefining innovation-eco-innovation research and the contribution from ecological economics. Ecological Economics, 32(2), 319-332.

Santos, F. M. (2012). A positive theory of social entrepreneurship. Journal of Business Ethics, 111(3), 335-351. 
Schaltegger, S., \& Wagner, M. (2011). Sustainable entrepreneurship and sustainability innovation: categories and interactions. Business Strategy and the Environment, 20(4), 222-237.

Sharir, M., \& Lerner, M. (2006). Gauging the success of social ventures initiated by individual social entrepreneurs. Journal of world business, 41(1), 6-20.

Shepherd, D. A., \& Patzelt, H. (2011). The new field of sustainable entrepreneurship: studying entrepreneurial action linking "what is to be sustained" with "what is to be developed". Entrepreneurship Theory and Practice, 35(1), 137-163.

Spence, L. et al. (2012). Environmental aspects of sustainability: SMEs and the role of the accountant. Research report 128. Association of Chartered Certified Accountants, London.

Stefanović, S., Ivanović-Djukić, M., \& Janković-Milić, V. (2013) The analysis of key challenges and constraints to the stability and growth of an entrepreneurial sector in Serbia, Journal of Balkan and Near Eastern Studies, Routledge London, 15(3), 346-365.

Thompson, N., Kiefer, K., \& York, J. G. (2011). Distinctions not dichotomies: Exploring social, sustainable, and environmental entrepreneurship. Social and Sustainable Entrepreneurship (Advances in Entrepreneurship, Firm Emergence and Growth, Volume 13) (pp. 201-229). Bingley: Emerald Group Publishing Limited.

WCED (1987). Our common future. World Commission on Environment and Development. Oxford: Oxford University Press.

York, J. G., \& Venkataraman, S. (2010), The entrepreneur-environment nexus: Uncertainty, innovation, and allocation, Journal of Business Venturing, 25, issue 5, p. 449-463, https:/EconPapers.repec.org/RePEc:eee:jbvent:v:25:y:2010:i:5 :p:449-463.

York, J. G., O’Neil, I., \& Sarasvathy, S. D. (2016). Exploring environmental entrepreneurship: identity coupling, venture goals, and stakeholder incentives. Journal of Management Studies, 53(5), 695-737.

Zahra, S. A., Gedajlovic, E., Neubaum, D. O., \& Shulman, J. M. (2009). A typology of social entrepreneurs: Motives, search processes and ethical challenges. Journal of Business Venturing, 24(5), 519-532. 